\title{
Changes of Petrov glacier and its proglacial lake in the Akshiirak massif, central Tien Shan, since 1977
}

\author{
Zbyněk ENGEL, ${ }^{1}$ Miroslav ŠOBR, ${ }^{1}$ Sergei A. YEROKHIN ${ }^{2}$ \\ ${ }^{1}$ Department of Physical Geography and Geoecology, Faculty of Science, Charles University in Prague, Prague, \\ Czech Republic \\ E-mail: engel@natur.cuni.cz \\ ${ }^{2}$ State Agency of Geology and Mineral Resources, Bishkek, Kyrgyzstan
}

\begin{abstract}
A combination of remotely sensed data, field mapping, bathymetric survey and geophysical soundings is used to describe the recent changes in the terminal area of Petrov glacier, the largest glacier in the Akshiirak massif, central Tien Shan. According to our results, three periods of accelerated glacier retreat (1977-80, 1990-95 and 2008-09) can be distinguished since 1977. The largest recession occurred in 1990-95 when the glacier retreated by $54 \pm 8 \mathrm{~m} \mathrm{a}^{-1}$. Accelerated glacier retreat affected the enlargement rate of Petrov lake, which increased by $0.04-0.1 \mathrm{~km}^{2} \mathrm{a}^{-1}$ and by $1.3-2.2 \times 10^{6} \mathrm{~m}^{3} \mathrm{a}^{-1}$ in the last three decades. Since 1995, the mean annual retreat rate of the lake-calving northern glacier section has been up to three times higher than the retreat rate of the land-terminating southern section. The calving flux ranged from 2.5 to $4.6 \times 10^{6} \mathrm{~m}^{3} \mathrm{a}^{-1}$ in $2003-09$, resulting in a total glacier mass loss of $(17.7 \pm 0.4) \times 10^{6} \mathrm{~m}^{3}$. The calving terminus of Petrov glacier was $>65 \mathrm{~m}$ thick in 2009 according to ground-penetrating radar measurements.
\end{abstract}

\section{INTRODUCTION}

Most glaciers in the Tien Shan have retreated at accelerating rates over the 20th century (Aizen and others, 2006; Li and others, 2006; Kutuzov and Shahgedanova, 2009). This retreat is particularly evident in the northern Tien Shan ranges, which are located at the transition between the mild temperate conditions of southern Siberia and the more severe continental climate of High Asia. Retreating glaciers have been reported from the central Tien Shan regions too, but with lower recession rates. Among the glacierized ranges, the Akshiirak massif has attracted the most attention because of its extensive glaciation, comprising 178 glaciers with a total area of $317.6 \mathrm{~km}^{2}$ (Aizen and others, 2006). Although most of the glaciers retreated over the 20th century, a prominent advance including surge-type movements has been reported for subperiods in the massif (Dolgushin and Osipova, 1982; Solomina and others, 2004). The overall balance of the glacierized area was negative in the last century: $82 \%$ of glaciers retreated, $14 \%$ were in a steady state and only 4\% advanced (Dyurgerov and others, 1995). The rate of glacierized area reduction was relatively low from 1943 to $1977\left(\sim 0.5 \mathrm{~km}^{2} \mathrm{a}^{-1}\right)$ but increased to $\sim 1.4 \mathrm{~km}^{2} \mathrm{a}^{-1}$ in 1977-2003 (Aizen and others, 2006).

Whereas the distribution and extent of glaciers in the central Tien Shan is relatively well known, information about the recent glacier fluctuations is comparatively poor, with the exception of the Akshiirak massif. The first record of glacier recession in this region was reported for the largest valley glacier in the Akshiirak massif, named Petrov by Kaulbars (1875) after the second lieutenant of his expedition. In 1869, Kaulbars described the area around the glacier terminus with a small lake in front of the terminal moraine. Davydov visited the area in 1911 and drew a sketch map of the glacier terminus with a lake within the terminal moraines. The outline is a rough approximation of the site and unfortunately does not help us to reconstruct the glacier terminus position. Davydov's (1927) report from his second visit to the area suggests that Petrov glacier was in a steady state between 1911 and 1925. Kalesnik and Epstein (1935) noted that the glacier terminus was located by the third inner ridge of the terminal moraine complex in 1932. Relics of this moraine probably form a part of the recent shoreline at the lake dam. An aerial survey carried out on behalf of the central government of the Soviet Union in Central Asia on 16 September 1943 revealed a retreat of Petrov glacier which terminated in a proglacial lake. According to Avsiuk (1953), the length of the glacier had decreased by $1.4 \mathrm{~m} \mathrm{a}^{-1}$ since 1911. However, this interpretation is very tentative as short glacier advances could have occurred during this period (Bondarev, 1963). Aerial photographs taken in 1957 show further recession of the glacier terminus, which retreated by about $400 \mathrm{~m}$ (Bondarev, 1963). Between 1957 and 1977 the length of the glacier decreased considerably (Sevast'yanov and Funtikov, 1981; Kuzmichenok, 1990). Fluctuations of the glacier at the end of the 20th century were described briefly by Aizen and others (2006) and Janský and others (2009). However, no field observation of the glacier has been available since the beginning of the 21 st century.

This paper presents results of monitoring changes in icecover extent of Petrov glacier in 2003-09. A synopsis of the historical evolution of this site was published by Janský and others (2009). In this paper, we present results of geomorphological and bathymetric investigations carried out on Petrov glacier and Petrov lake from 2006 to 2009. Our first aim is to reconstruct the recent fluctuations of Petrov glacier. The second objective is a detailed description of recent changes in the proglacial area including volume changes of Petrov lake.

\section{STUDY AREA}

Petrov glacier and its proglacial lake are situated in the Akshiirak massif $\left(41^{\circ} 40^{\prime}-42^{\circ} 05^{\prime} \mathrm{N} ; 78^{\circ} 00^{\prime}-78^{\circ} 35^{\prime} \mathrm{E}\right.$; $938 \mathrm{~km}^{2}$ ), central Tien Shan. The massif consists of three mountain ranges with a southwest orientation. The ranges 


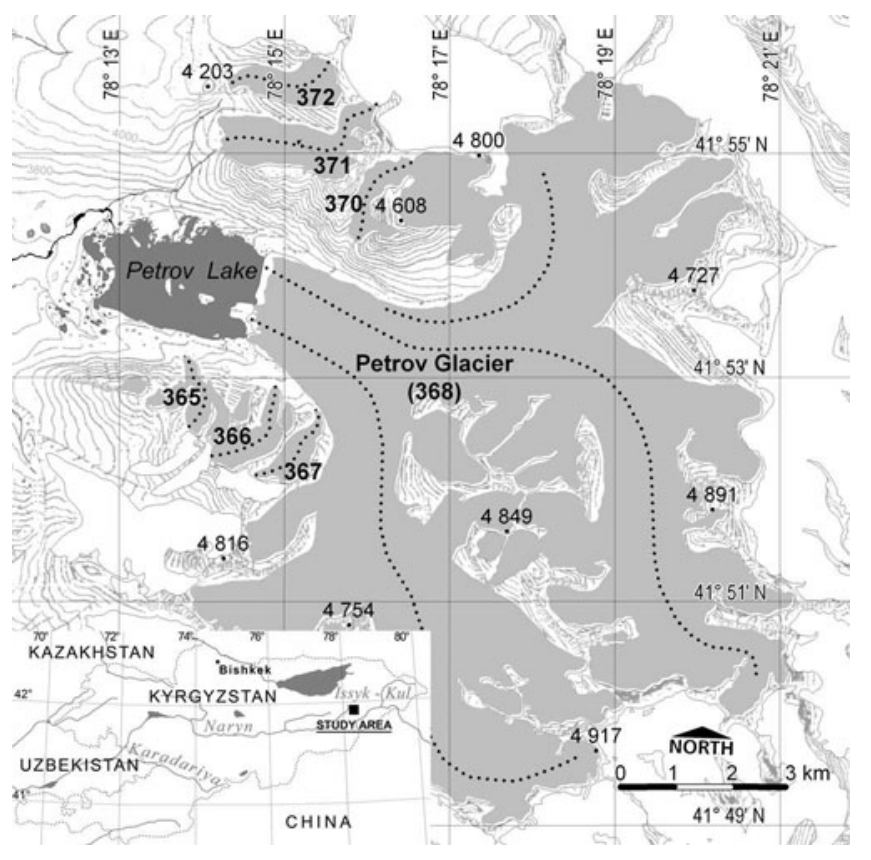

Fig. 1. Location map of glaciers in the study area, showing glacier numbers and flowlines. The dark-grey textured glaciers drain into the Kumtor river, whereas glaciers plotted in white are situated beyond the watershed. Distribution of glaciers after Khromova (2005), numerical data after Suslov (1973).

are elevated $1200-1400 \mathrm{~m}$ above the surrounding relief. Well-developed glacial landforms and extensive glaciation covering $371.6 \mathrm{~km}^{2}$ (Aizen and others, 2006) are characteristic features of the massif. The study area is located on the northwestern slope of the Akshiirak massif, which rises above a gently sloping valley of the Kumtor river. Petrov glacier terminates in a wide valley with relatively low and slightly inclined slopes. The proglacial Petrov lake $(3741 \mathrm{~m}$ a.s.I.) stretches $2.9 \mathrm{~km}$ from the glacier terminus towards the west-northwest, where it is dammed by a system of terminal moraines. A surface outflow is situated in the northern part of the moraine (Fig. 1). The moraine dam comprises till of three to five stages of glaciation, with the most prominent stage correlated with the Little Ice Age period (Bondarev, 1963; Savoskul, 1995). A number of thermokarst lakes in the dam document the presence of massive ice in the recently exposed moraines. Degradation of the buried ice is accompanied by relief sinking, mass movements and potholing (Janský and others, 2009). On the distal side of the moraine complex the glaciofluvial sediments cover the bottom of the Kumtor valley, which is up to $1.5 \mathrm{~km}$ wide. From the north, a tributary hanging valley runs into the right slope of the main valley $100 \mathrm{~m}$ above Petrov lake. The slopes of the valley around the lake consist of Carboniferous limestone and sandstone, while the eastern part of the valley consists mainly of Lower Carboniferous gneiss and schist (Ivanov, 1964). Proterozoic granitoids surround the accumulation area of Petrov glacier in the central part of the Akshiirak massif.

The glacierized area is dominated by Petrov glacier, which is a large dendritic valley glacier (Fig. 1). The glacier is characterized by an accumulation-area ratio value of 0.6 , long constituent flow units, low average slope angle $\left(<10^{\circ}\right)$ and an even longitudinal profile. The glacier is not considered a surge-type glacier, unlike Northern Karasai or
Table 1. Morphologic characteristics of glaciers in study area

\begin{tabular}{|c|c|c|c|c|c|}
\hline \multirow[t]{2}{*}{ Name/No.* } & \multirow[t]{2}{*}{ Type } & \multirow[t]{2}{*}{ Aspect } & \multirow{2}{*}{$\begin{array}{l}\text { Area }^{\dagger} \\
\mathrm{km}^{2}\end{array}$} & \multirow{2}{*}{$\begin{array}{l}\text { Length } \\
\text { km }\end{array}$} & \multirow{2}{*}{$\begin{array}{c}\text { Terminus } \\
\text { altitude } \\
\text { m a.s.l. }\end{array}$} \\
\hline & & & & & \\
\hline 365 & Hanging & $\mathrm{N}$ & 0.65 & 1.4 & 3780 \\
\hline 366 & Hanging & $\mathrm{NE}$ & 0.71 & 1.9 & 3880 \\
\hline 367 & Hanging cirque & NE & 0.52 & 1.7 & 3950 \\
\hline Petrov/368 & Valley & W & 58.9 & 12.1 & 3740 \\
\hline 370 & Hanging cirque & SW & 0.65 & 1.8 & 4150 \\
\hline 371 & Valley & W & 1.87 & 3.0 & 3930 \\
\hline 372 & Valley & W & 1.00 & 1.9 & 4050 \\
\hline
\end{tabular}

*Suslov (1973). †'Khromova (2005).

Bordu in the southern part of the Akshiirak (Bondarev, 1963; Dolgushin and Osipova, 1982). Two small valley glaciers fill the bottom of deeply incised tributary valleys located north of Petrov lake (Fig. 1; Table 1). These glaciers have irregular longitudinal profiles, higher slope angles $\left(10-15^{\circ}\right)$ and shorter response times than Petrov glacier. The equilibrium line-altitude (ELA) in the region ranged from 4150 to $4340 \mathrm{~m}$ a.s.I. between 1985 and 1989 (Dyurgerov and others, 1995).

The study area falls within the zone of mountain permafrost. The lower limit of continuous permafrost in the Akshiirak region is located at 3500-3600 m a.s.l. (Dikich and others, 1991; Gorbunov and others, 1996). Based on ground temperature measurements in nearly 50 boreholes, the permafrost is up to $370 \mathrm{~m}$ thick (Ermolin and others, 1989). Since the lower limit of continuous mountain permafrost is well below the ELA, we expect that glaciers in the study area are mostly cold-based. The sporadic data on thermal regimes of glaciers in nearby ranges (Dyurgerov and others, 1995) support this view.

The region is characterized by a continental climate with marked seasonal variation. Climate conditions are affected by the position of the Akshiirak massif, which represents an obstacle for western transport of moist Atlantic air masses. In the zone of predominantly westerly winds, precipitation mainly falls in the spring and summer months, while the winters are cold and dry. Mean annual precipitation (MAP) reaches $291 \mathrm{~mm}$, with $45 \%$ occurring during the more humid season from June to August (Tien Shan meteorological station data, 1930-97). Mean January, July and annual air temperatures (MAAT) are $-21.7^{\circ} \mathrm{C}, 4.5^{\circ} \mathrm{C}$ and $-7.6^{\circ} \mathrm{C}$, respectively (1930-97). According to continuous meteorological data collected before the replacement of the Tien Shan meteorological station in 1997, air temperature has increased since 1930, but no significant trend in precipitation has occurred (Solomina and others, 2004; Aizen and others, 2007).

\section{MATERIALS AND METHODS}

\section{Remote-sensing data and maps}

Aerial photographs and satellite images were used to determine glacier terminus changes since the mid-20th century (Table 2). The paper prints of the aerial photographs and a sheet of $1: 25000$ topographic map based on aerial survey from 1977 were scanned at $600 \mathrm{dpi}$ and registered using coordinates of control points. A Trimble GeoXH GPS 
Table 2. Overview of maps, aerial photographs and satellite imageries used in the study

\begin{tabular}{cccc}
\hline Data type & $\begin{array}{c}\text { Acquisition } \\
\text { date }\end{array}$ & Resolution & $\begin{array}{c}\text { Registration } \\
\text { error }\end{array}$
\end{tabular}

$\mathrm{m}$

$\mathrm{m}$

\begin{tabular}{lccr}
\hline Aerial photographs & 2 Oct. 1957 & 1.5 & 8.3 \\
& 24 Aug. 1980 & 1.7 & 4.6 \\
& 19 Sep. 1995 & 0.5 & 4.5 \\
Topographic map & 1977 & 5 & 10.1 \\
$\begin{array}{l}\text { U-41-82-B- }{ }^{*} \\
\text { Landsat Thematic Mapper }\end{array}$ & 31 Jul. 1990 & 30 & 9.9 \\
$\begin{array}{l}\text { (TM) } \\
\text { Landsat Enhanced TM+ }\end{array}$ & 18 Sep. 1999 & 15 & 8.4 \\
QuickBird (panchromatic) & 19 Sep. 2003 & 0.6 & 2.0
\end{tabular}

*Main Department of Geodesy and Cartography of the USSR (1981).

receiver (Trimble, 2009) was used to determine coordinates for the points. Averaging and accuracy-based logging were applied to ensure horizontal root-mean-square (rms) position accuracy $<3.5 \mathrm{~m}$. The Landsat and QuickBird data were georeferenced using 7-11 control points. The pixel resolution of the data and registration rms errors are summarized in Table 2. The uncertainty associated with glacier terminus changes between two dates was calculated as the sum of the resolution-related uncertainty and uncertainty due to errors in registration of dataset pairs ( $\mathrm{Li}$ and others, 2006). The partial uncertainties are estimated using

$$
U=\sqrt{R_{\mathrm{a}}^{2}+R_{\mathrm{b}}{ }^{2}},
$$

where $R_{\mathrm{a}}$ and $R_{\mathrm{b}}$ are the resolution or registration errors of images a and b, respectively ( $\mathrm{Li}$ and others, 2006). The uncertainties in the area extent are determined using

$$
a=A(2 d / x),
$$

where $A=x^{2}, x$ is the image resolution and $d$ is the uncertainty related to the spatial resolution of the dataset (Hall and others, 2003). The calculated uncertainties are listed in Table 3.

\section{Field mapping and geophysical soundings}

Combined GPS/geodetic mapping of glacier limits and landforms in the proglacial area was carried out on 411 July 2006, 12-13 August 2008 and 5-9 September 2009. A Trimble GeoXH GPS was used to delimit accessible boundaries of the glaciers and to determine coordinates for the base points of geodetic measurements with rms accuracy $<3.5 \mathrm{~m}$. The calving terminus of Petrov glacier was located using a pulsed laser rangefinder of a Leica TCR 705 total station in non-prism mode. Though the declared accuracy of non-prism mode measurement is $3 \mathrm{~mm}(+2 \mathrm{ppm} \times$ measuring distance) the overall accuracy of measurement was determined by the GPS positioning of the base points. The collected positional data were analysed in conjunction with remote-sensing imagery using a GIS (Maplnfo Professional 10.0) in order to quantify length and area fluctuations of Petrov glacier and its lake.

Ground-penetrating radar (GPR) was used at the terminus of Petrov glacier to acquire information on glacier thickness and subglacial topography. GPR data were collected along a profile that was perpendicular to the centre flowline of Petrov
Table 3. Uncertainty associated with the Petrov glacier terminus change

\begin{tabular}{lccc}
\hline Period & $\begin{array}{c}\text { Resolution } \\
\text { uncertainty } \\
\mathrm{m}\end{array}$ & $\begin{array}{c}\text { Registration } \\
\text { uncertainty } \\
\mathrm{m}\end{array}$ & Total uncertainty \\
& & & $\mathrm{m}$ \\
\hline $1957-77$ & 5.2 & 13.0 & 18.3 \\
$1977-80$ & 5.3 & 11.1 & 16.3 \\
$1980-90$ & 30.0 & 10.9 & 40.9 \\
$1990-95$ & 30.0 & 10.8 & 40.8 \\
$1995-99$ & 15.0 & 9.5 & 24.5 \\
$1999-2003$ & 15.0 & 8.6 & 23.6 \\
$2003-06$ & 3.6 & 2.0 & 5.6 \\
& & & \\
\hline
\end{tabular}

glacier and lay on average $130 \mathrm{~m}$ from the glacier terminus. The location of the profiles was chosen so that measurements described the whole width of the glacier. An unshielded $50 \mathrm{MHz}$ RTA (Rough Terrain Antenna) and MALA CU-II control unit (MALA GeoScience, 2005) were used for data collection. The signal acquisition time was set to $860 \mathrm{~ns}$, and scan spacing was about $0.07 \mathrm{~m}$. GPR soundings were done on 8 September 2009 in favourable dry conditions. The collected data were processed and interpreted using the Reflex-Win software version 4.5. The depth axis of profiles was calculated from the time axis and the wave velocity for glacier ice $\left(0.167 \mathrm{~m} \mathrm{~ns}^{-1}\right)$. The permittivity for glacier ice corresponds with the value of 3.17 (Davis and Annan, 1989).

\section{Bathymetric survey}

A bathymetric survey was conducted in September 2009 to determine volume changes of Petrov lake resulting from the retreat of the glacier terminus. An echo sounder was used on 33 profiles that were either parallel or perpendicular to the longitudinal axis of the lake. The location of the profiles was chosen so that measurements described the whole area of the lake regularly. A Garmin GPSmap 178C Sounder with GA 29 external antenna (Garmin, 2007) was used for depth measurements, which were taken at $10 \mathrm{~m}$ intervals. The horizontal accuracy of depth measurement points was controlled during the survey, and individual points with a horizontal rms over $5 \mathrm{~m}$ were indicated. Vertical resolution of depth measurement using a frequency of $200 \mathrm{kHz}$ was $\sim 0.3 \mathrm{~m}$. Depth measurements were validated using a plummet in various depths and parts of the lake.

The raw bathymetric data were referenced and processed using GIS. Depth measurement points (43) with a horizontal rms $>5 \mathrm{~m}$ were removed from the measurement log. A verification set of 160 randomly selected measurement points was extracted from the data in order to validate the accuracy of interpolated bathymetric models. The remaining 7039 point measurements together with the shoreline, which represents the zero level, were used for interpolation. The shoreline and position of the calving terminus of Petrov glacier were constructed for 2003 using QuickBird imagery. Terminus positions for 2006, 2008 and 2009 are based on GPS/total-station measurements. Different interpolation techniques (inverse distance weighing, kriging, minimum curvature, spatial neighbour and triangulation) with optimized parameters were applied to the bathymetric dataset for 2009 to create a digital elevation model (DEM) of the lake basin. The accuracy of the model was subsequently 


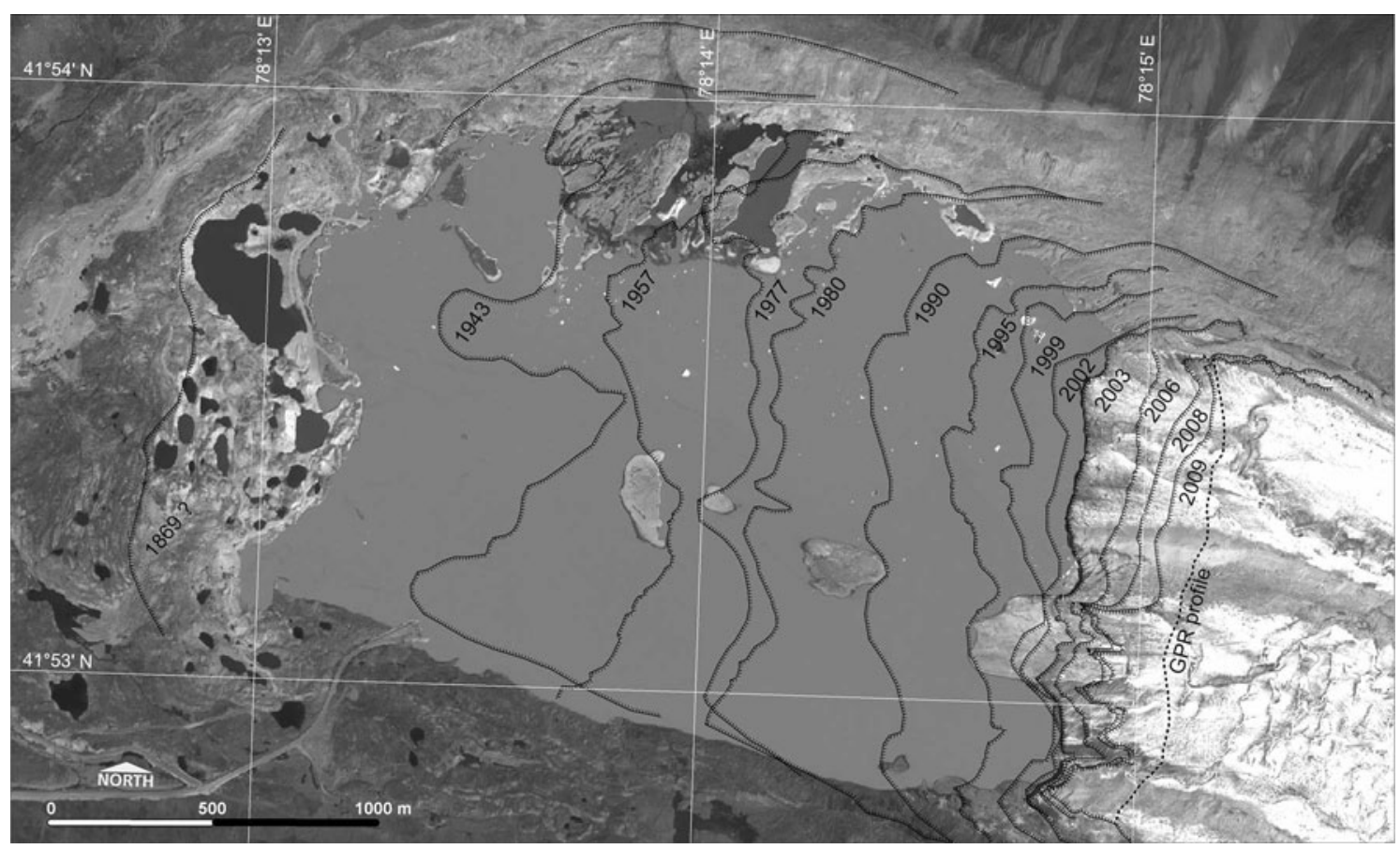

Fig. 2. Positions of the Petrov glacier terminus over the 20th century. The map documents the expansion of the proglacial lake from 1943 to 2003. QuickBird image (2003).

cross-validated using the verification set of measurement points. The sum of residuals and appearance of the lake basin morphology were used to determine the most reliable gridding method. The spatial neighbour interpolation, which generated a smoother surface and low mean square error, was then used to construct $5 \mathrm{~m}$ gridcell DEMs for 2003, 2006 and 2008. The Petrov lake volume changes were estimated for three subsequent periods (2003-06, 2006-08 and 2008-09) using the difference between volumes computed from relevant DEMs.

The bathymetric data were also used to calculate the calving flux of the northern lake-calving section of Petrov glacier. Measured depth data and the 2003 DEM of the glacier surface provided by Kumtor mining company (Canada) were used for this purpose. The DEM with a vertical resolution of $4 \mathrm{~m}$ is based on high-resolution space images. The data that represent the base and surface topography of the glacier allowed the DEM of the calving glacier terminus to be constructed. The same interpolation technique as for the bathymetric model was used to construct DEMs for 2003, 2006, 2008 and 2009. The total volume of calving glacier terminus mass loss was estimated for the periods 2003-06, 2006-08 and 2008-09 using differences between relevant DEM pairs.

\section{Climate and discharge data}

Monthly air-temperature and precipitation data from the Tien Shan meteorological station were analysed for trends over the measurement period (1930-2009). Since the station was transferred from the Kumtor valley bottom $(3614 \mathrm{~m}$ a.s.I.) to a more elevated site $(3660 \mathrm{~m}$ a.s.I.) on the east side of the valley $\left(41^{\circ} 53^{\prime} \mathrm{N}, 78^{\circ} 9^{\prime} \mathrm{E} ; 6.7 \mathrm{~km}\right.$ east-northeast of the study site) in 1997, the homogeneity of measured data was tested first using an analysis of variance (ANOVA). The tests showed significant differences between 1930-97 and 19982009 time series for both air temperature $(F=4.44, p=0.04)$ and precipitation $(F=4.81, p=0.03)$. Therefore, the time series were analysed separately. As warm-season temperatures (WST) recorded from May to September and annual solid precipitation are the main factors controlling glacier mass balance (Voloshina, 1988), simple linear regression was used to uncover trends in these factors. Finally, the relationship between these factors and the reconstructed retreat rate of Petrov glacier was evaluated using a $t$-test.

Measurements of the Kumtor river discharge were analysed as an indicator of seasonal and annual variation in mass balance of Petrov glacier. Daily averaged discharge data are available for a site located $\sim 5 \mathrm{~km}$ below the stream outflow from Petrov lake. Regular observations have been maintained by the Kumtor mining company since 2001. The relationship between discharge, climate data and the retreat rate of Petrov glacier was assessed. The correlation coefficient factors, $r$, were calculated within a $95 \%$ confidence level, and the statistical significance of regression was assessed based on the $p$-value for the $F$-test.

\section{RESULTS}

\section{Fluctuations of Petrov glacier}

Two major periods of Petrov glacier fluctuations may be distinguished since the first investigations in 1869. From 1869 to 1977, the terminus of Petrov glacier seems to have undergone relatively small annual oscillations showing similar changes in both northern and southern sections (Fig. 2). During this period, the glacier retreated at a mean rate of $13.6 \mathrm{~m} \mathrm{a}^{-1}$. At the end of the $1970 \mathrm{~s}$, the recession accelerated substantially and the land-based and calving sections of the Petrov glacier terminus retreated at different rates. Since 1977, linear retreat rates have not dropped below $33.6 \pm 1.9 \mathrm{~m} \mathrm{a}^{-1}$, with a mean value of $40.6 \pm 0.5 \mathrm{~m} \mathrm{a}^{-1}$. The surface area of the glacier terminus decreased at a rate of $0.07 \pm 0.0002 \mathrm{~km}^{2} \mathrm{a}^{-1}$ over the period 1977-2009.

The last three decades may be divided into five periods: three periods (1977-80, 1990-95 and 2008-09) marked by 


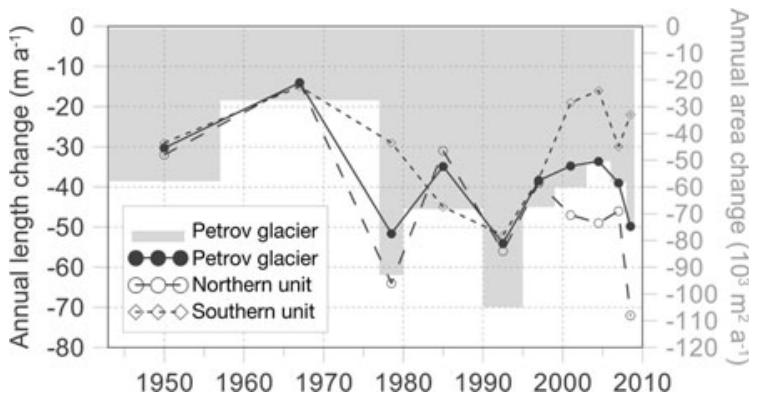

Fig. 3. Mean annual variations of the Petrov glacier length (solid line) and area (grey shading) since 1943. Dotted and dashed lines represent length changes of the southern and northern flow units, respectively.

a rapid retreat of the glacier terminus, and two intermediate periods during which the rate of recession remained almost constant (Fig. 3). Between 1977 and 1980 the mean retreat rate for Petrov glacier reached $51.6 \pm 5.4 \mathrm{~m} \mathrm{a}^{-1}$, which is the second highest value over the period 1869-2009 (Table 4). The more intensive fluctuations occurred in the calving part of the glacier, with a rate of recession exceeding $66.1 \pm 5.4 \mathrm{~m} \mathrm{a}^{-1}$. Between 1980 and 1990 the retreat rate of Petrov glacier decreased to $34.9 \pm 4.1 \mathrm{~m} \mathrm{a}^{-1}$, and the southern flow unit retreated at a mean rate 1.5 times higher than the northern flow unit. The recession of Petrov glacier increased considerably from 1990 to 1995 , reaching the highest recorded retreat rate $\left(54.1 \pm 8.2 \mathrm{~m} \mathrm{a}^{-1}\right)$. A subsequent period is marked by a relatively steady retreat rate, which increased again after 2008 for the northern flow unit. Over the period 1995-2009 the northern terminus of Petrov glacier retreated at a rate up to three times higher than the southern terminus.

The increased retreat rate of Petrov glacier in the last two decades coincides with observed changes in adjacent valley glaciers N. 371 and N. 372. These glaciers retreated from 1943 to 1977 by as much as $250 \mathrm{~m}$ and slightly advanced in the 1980s (Meiners, 1997). Between 1990 and 2009 the lengths of the glaciers decreased by up to $100 \pm 40 \mathrm{~m}$, representing a mean retreat rate of $5 \pm 2 \mathrm{ma}^{-1}$. The retreat rate
Table 5. Area and volume changes of Petrov lake

\begin{tabular}{llccc}
\hline Year & \multicolumn{2}{c}{ Area } & \multicolumn{2}{c}{ Volume } \\
& Total & Annual change & Total & Annual change \\
& $\mathrm{km}^{2}$ & $\mathrm{~km}^{2}$ & $10^{6} \mathrm{~m}^{3}$ & $10^{6} \mathrm{~m}^{3}$ \\
& & & & \\
\hline 1943 & 0.85 & - & & \\
1957 & 0.96 & 0.008 & & - \\
1978 & $1.63 *$ & 0.032 & $20^{*}$ & \\
1980 & 1.83 & 0.100 & & 1.3 \\
1995 & 2.78 & 0.063 & & 1.4 \\
2003 & 3.66 & 0.110 & 53.4 & 2.2 \\
2006 & 3.80 & 0.047 & 59.2 & \\
2008 & 3.88 & 0.037 & 62.0 & \\
2009 & 3.94 & 0.059 & 64.3 &
\end{tabular}

*After Sevast'yanov and Funtikov (1981).

accelerated during the period 2006-09 to $11.0 \pm 1.6 \mathrm{~m} \mathrm{a}^{-1}$, which is the highest observed rate since 1957.

\section{Petrov lake enlargement}

A small proglacial lake that first appeared in the 1930s extended slowly until the late 1970s (Table 5). After 1978 the surface enlargement increased and remained relatively high for the next three decades. Slightly higher surface changes occurred in the periods 1978-80 and 1995-2003, when the lake area increased yearly by $\sim 0.1 \mathrm{~km}^{2}$. The progress of the lake volume changes had a similar pattern to the largest increase after 1978. An accelerated increase in the volume was recorded in 2003-06 when the glacier terminus retreated into the deepest part of the lake basin. After a minor decrease of the volume change during 2006-08, the lake grew by $(2.2 \pm 0.009) \times 10^{6} \mathrm{~m}^{3}$ from 2008 to 2009 .

The eastern shoreline of the lake changed considerably between 2003 and 2006. The southern section of the Petrov glacier terminus retreated from the lake, and a till sheet and glaciofluvial fan became the main landforms of the lake shore. In the same period, the northern part of Petrov lake expanded into the deepest part $(70 \mathrm{~m})$ of the lake basin (Janský and others, 2009). The bottom of the basin is wide

Table 4. Length and area changes of Petrov glacier and its constituent flow units

\begin{tabular}{|c|c|c|c|c|c|c|c|c|}
\hline \multirow[t]{2}{*}{ Period } & \multirow{2}{*}{$\begin{array}{l}\text { Length change* } \\
\text { Petrov glacier } \\
\text { m }\end{array}$} & \multicolumn{3}{|c|}{ Annual length change ${ }^{\dagger}$} & \multirow{2}{*}{$\begin{array}{c}\text { Area change } \\
\text { Petrov glacier } \\
\mathrm{km}^{2}\end{array}$} & \multicolumn{3}{|c|}{ Annual area change } \\
\hline & & $\begin{array}{c}\text { Petrov glacier } \\
\mathrm{m} \mathrm{a}^{-1}\end{array}$ & $\begin{array}{c}\mathrm{N} \text { flow unit } \\
\mathrm{ma}^{-1}\end{array}$ & $\begin{array}{l}\text { S flow unit } \\
\mathrm{m} \mathrm{a}^{-1}\end{array}$ & & $\begin{array}{c}\text { Petrov glacier } \\
\mathrm{km}^{2} \mathrm{a}^{-1}\end{array}$ & $\begin{array}{l}\mathrm{N} \text { flow unit } \\
\mathrm{km}^{2} \mathrm{a}^{-1}\end{array}$ & $\begin{array}{c}\text { S flow unit } \\
\mathrm{km}^{2} \mathrm{a}^{-1}\end{array}$ \\
\hline 1869-1943 & -880 & -11 & - & - & -1.994 & -0.027 & - & - \\
\hline $1943-57$ & -500 & -30 & -32 & -29 & -0.810 & -0.058 & -0.032 & -0.026 \\
\hline 1977-80 & -290 & -52 & -66 & -29 & -0.279 & -0.093 & -0.073 & -0.020 \\
\hline 1980-90 & -250 & -35 & -31 & -45 & -0.683 & -0.068 & -0.034 & -0.034 \\
\hline 1990-95 & -260 & -54 & -56 & -52 & -0.525 & -0.105 & -0.059 & -0.046 \\
\hline 1995-99 & -120 & -38 & -39 & -38 & -0.270 & -0.068 & -0.038 & -0.029 \\
\hline 1999-2003 & -260 & -35 & -47 & -19 & -0.241 & -0.060 & -0.046 & -0.015 \\
\hline 2003-06 & -150 & -34 & -49 & -16 & -0.151 & -0.050 & -0.039 & -0.011 \\
\hline 2006-08 & -100 & -39 & -46 & -30 & -0.117 & -0.058 & -0.038 & -0.020 \\
\hline 2008-09 & -70 & -50 & -72 & -22 & -0.075 & -0.075 & -0.059 & -0.014 \\
\hline
\end{tabular}

*Calculated as linear difference between two subsequent positions of glacier terminus measured along central axis.

${ }^{\dagger}$ Calculated as area change between two subsequent positions of glacier front divided by width of glacier. 


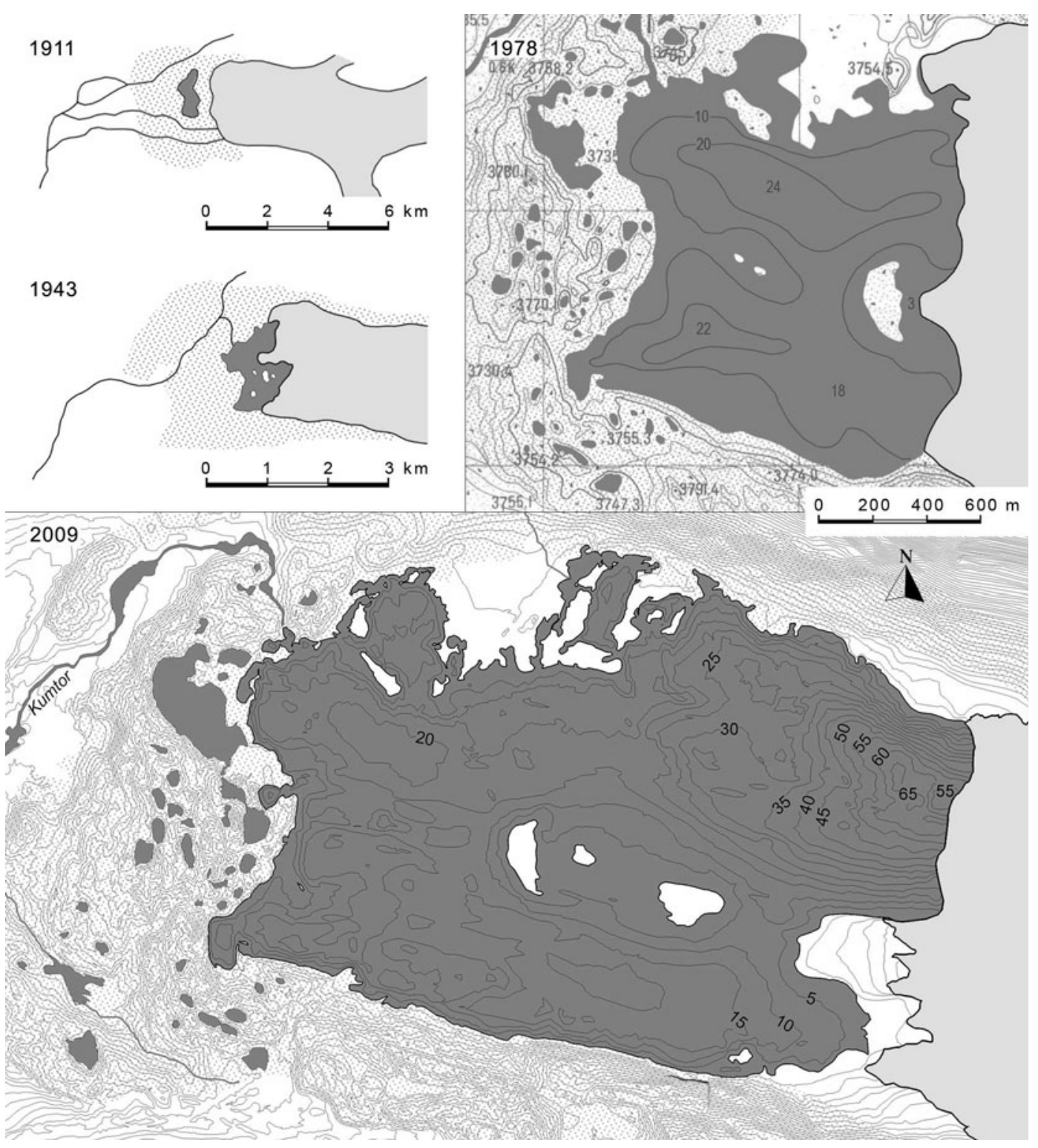

Fig. 4. Evolution of Petrov lake between 1911 and 2009. Dark and light grey areas represent lakes and glaciers, respectively. Dotted textures delimit moraines. Modified after Davydov (1927), Avsiuk (1953) and Sevast'yanov and Funtikov (1981).

and relatively flat in this area (Fig. 4). The retreat of Petrov glacier after 2006 led to an expansion of the lake into a shallower part of the basin in front of the calving terminus, which is characterized by convergence of contours towards the central line.

\section{Morphology of the Petrov glacier terminus}

The different behaviour of the northern and southern sections of the terminus of Petrov glacier has affected the shape and surface morphology of the terminus. The steep calving terminus has the form of a cliff with numerous crevasses that extend hundreds of metres back into the glacier (Fig. 5). The rugged surface indicates relatively high activity of the flow unit which is manifested in frequent calving. The higher mass turnover led to the rapid retreat of the calving terminus and to the ice front lowering by about $5 \mathrm{~m}$ between 2006 and 2009. In contrast, the landterminating glacier front is marked by predominantly moderate slope angle and lower crevasse density. The smoother ice surface may be directly related to a lower

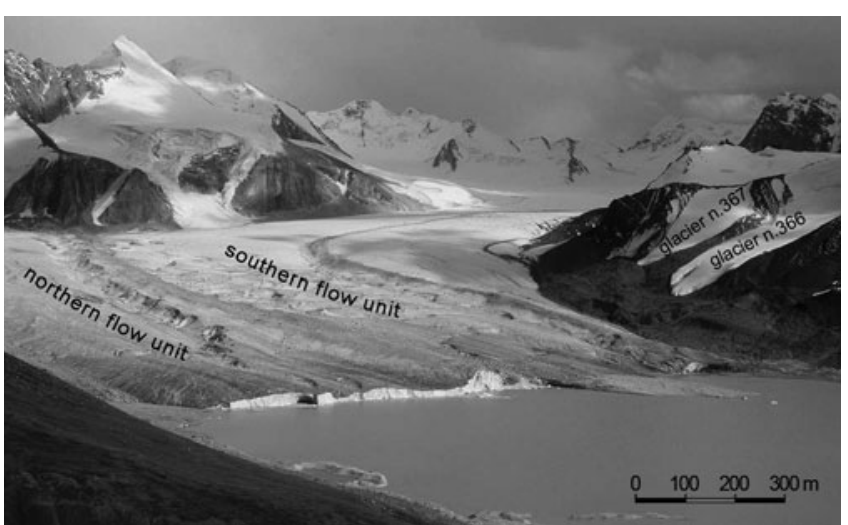

Fig. 5. Terminus of Petrov glacier in July 2005. The northern part of the glacier borders the eastern shore of Petrov lake whereas the southern flow unit terminates on the former glacier bed $30-70 \mathrm{~m}$ from the shoreline. Photo: Z. Engel. 


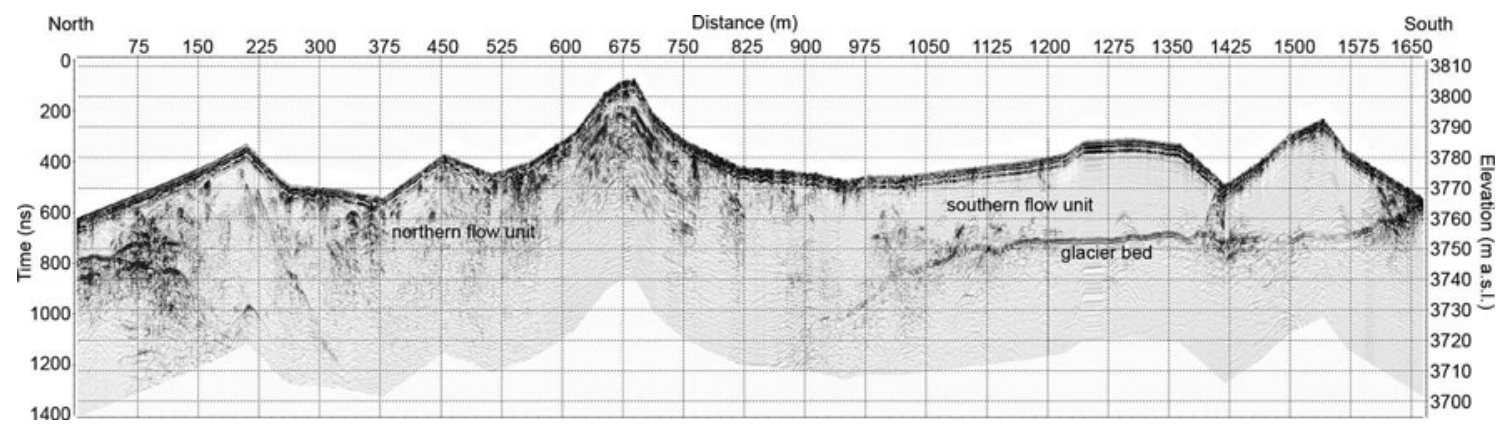

Fig. 6. A $50 \mathrm{MHz}$ GPR section for the terminal part of Petrov glacier. The most prominent reflection corresponds to the lower limit of the glacier.

tensile stress and mass exchange on the southern flow unit. The marginal parts of the terminus were frozen to the ground, as observed in subglacial cavities in central and southern parts of the terminus. The GPR data show a distinctive reflection boundary corresponding to an ice-bed boundary of Petrov glacier. The amplitude of reflections is smaller in the area below the northern flow unit, implying transition from ice to subglacial till rather than to solid bedrock. Applying a wave velocity of $0.167 \mathrm{~m} \mathrm{~ns}^{-1}$ for the depth calculation, the thickness of the northern flow unit exceeds $65 \mathrm{~m}$ and the maximum depth of the southern flow unit is $38 \mathrm{~m}$ (Fig. 6)

The effects of uneven ablation were observed on the glacier terminus during 2005-09. The repeated measurements of the terminus position confirmed a remarkable retreat and surface lowering of the glacier sections exposed to direct insolation, which were $130-240 \mathrm{~m}$ further up the valley, and up to $5 \mathrm{~m}$ lower, in 2009 than in 2006. In contrast, debris-covered parts of the glacier terminus retreated by up to $135 \mathrm{~m}$, and the surface lowering was smaller than $2 \mathrm{~m}$ according to repeat elevation measurements. The thickness of the debris cover ranged from tenths of a metre to about $1.5 \mathrm{~m}$. The total amount of iceberg calving from the northern glacier terminus accounted for the total mass loss of $(17.7 \pm 0.4) \times 10^{6} \mathrm{~m}^{3}$ from 2003 to 2009 . The mean annual calving flux increased from $(2.5 \pm$ $0.06) \times 10^{6} \mathrm{~m}^{3}$ in $2003-06$ to $(4.6 \pm 0.09) \times 10^{6} \mathrm{~m}^{3}$ in 2008-09. Subaerial calving was observed during our fieldwork in 2006 and 2009, when small sections of the cliff were calved off once every day or two, forming icebergs up to $8 \mathrm{~m}$ long. The presence of a number of larger icebergs along the cliff indicates that subaqueous calving may contribute to the disintegration of the glacier terminus.

\section{Climate and discharge variations}

Analyses of meteorological data from the Tien Shan station show a statistically significant increase in WST $(r=0.323$, $p=0.06)$ and decrease in MAP $(r=-0.343, p=0.04)$ in the period 1930-97. In contrast, no significant trend was observed in the period 1998-2009. The air-temperature record indicates that WST increased by $0.8^{\circ} \mathrm{C}$ between the periods 1930-97 and 1998-2009 (Fig. 7). At the same time, MAAT increased by $1.8^{\circ} \mathrm{C}$, and the period of positive air temperatures extended from 3.6 to 4.2 months. However, the inferred increase in temperature is complicated by the relocation of the meteorological station. MAP increased by $60 \mathrm{~mm}$ between the two time series. The increase of precipitation was limited to the warm season only. During the remaining months, precipitation slightly decreased.
Discharge recordings of the Kumtor river have not revealed any trend for the period 2001-09 (Fig. 8). A positive correlation $(r=0.74, p=0.02)$ between discharge and WST exists, but no statistically significant correlation was found between discharge and precipitation. A maximum discharge is seen in the late warm season (August), 1 month after the warmest month and 2 months after the maximum precipitation (Fig. 9). The delay of the glacier discharge results from the retaining of precipitation in the watershed (net glacier storage) during the accumulation season.

\section{DISCUSSION}

The rapid retreat of Petrov glacier in the period 1943-57 described above is consistent with intense recession of large dendritic glaciers in the Tien Shan. In the Akshiirak massif, most of the valley glaciers retreated by up to $50 \mathrm{~m} \mathrm{a}^{-1}$ during this period (Bondarev, 1963). Increased rate of glacier retreat was also reported from the nearby Terskey-Alatoo (Kutuzov and Shahgedanova, 2009), the Khan Tengri massif (Koshoev, 1986) and the Kyrgyz Range (Aizen and others, 2006). From 1957 to 1977, the retreat rate of Petrov glacier decreased, coincident with reduced recession of glaciers throughout the northern and central Tien Shan (Makarevich and Liu, 1995). According to Aizen and others (2006), mean retreat rates of glaciers in the Akshiirak ranged from 5 to $19 \mathrm{~m} \mathrm{a}^{-1}$ over this period. Despite the overall glacier recession in the 1960s and the first half of the 1970s, many glaciers in the northern Tien Shan were in equilibrium, or even advancing slightly (Maksimov, 1980; Yermolov and others, 1986; Vilesov and others, 1993). In contrast, the recession of Ürümqi glacier No. 1, eastern Tien Shan, was most rapid from the 1960s to the mid-1970s, when the retreat rate decreased substantially (Yao and others, 2004). These differences result from more variable climate conditions in peripheral mountain areas (Aizen and Aizen, 1994).

In the late 1970s, a period of minor glacier recession in the study area changed to a rapid retreat. The observed rapid retreat event of Petrov glacier supports the fluctuation scheme described by Aizen and others (2006) in the Kyrgyz Range where Golubina glacier retreated by $18 \mathrm{ma}^{-1}$ in 1976-78. Although the glacier retreat in the study area had decreased in 1980, it remained significantly higher than in the period 1957-77. The rapid glacier retreat observed in the study area in the 1980s and 1990s coincides with increased glacier recession that was reported from numerous Tien Shan ranges (Aizen and Aizen, 1994; Vilesov and Uvarov 2001; Aizen and others, 2006; Li and others, 2006; Bolch, 2007; Niederer and others, 2008) including the Akshiirak 


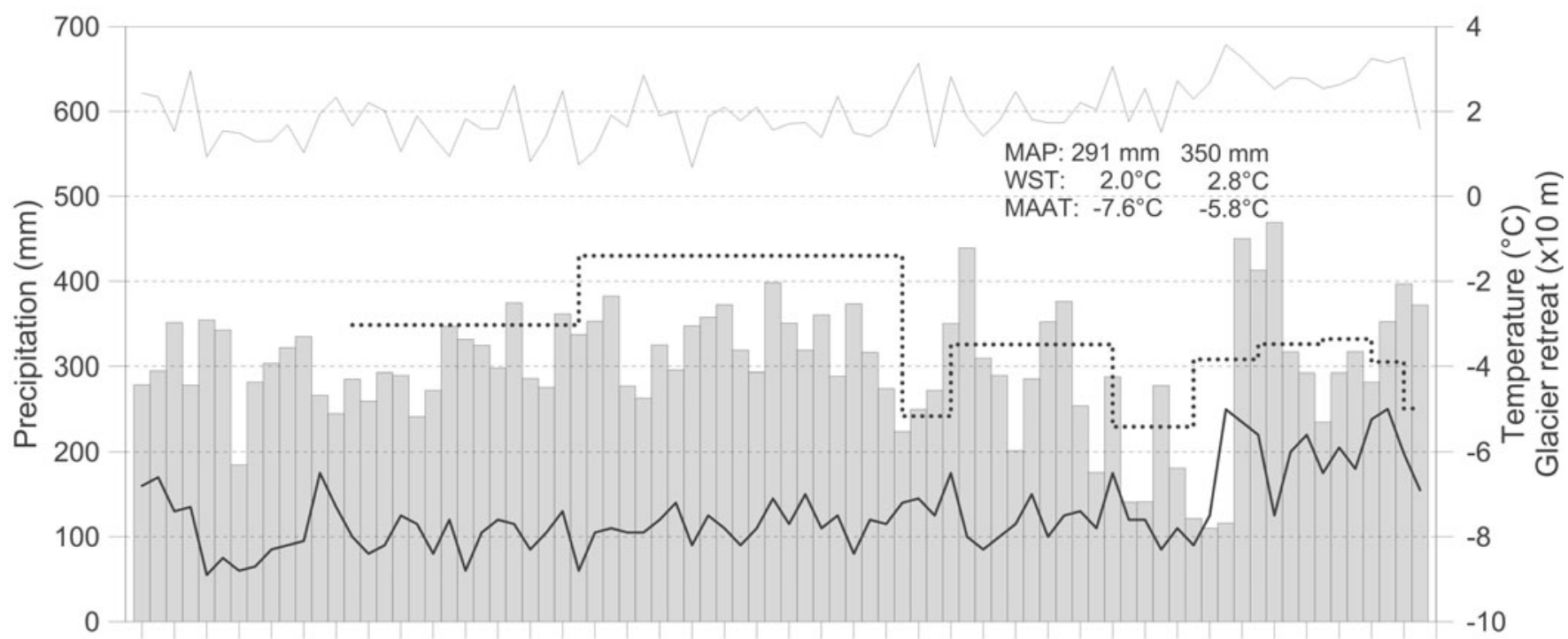

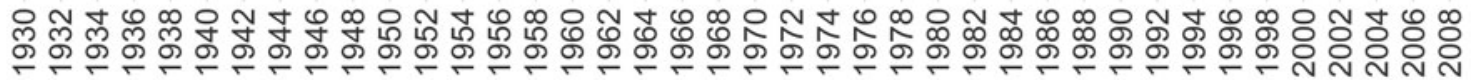

Fig. 7. Mean annual precipitation (bars), mean annual (bold line) and warm-season temperature (grey line) at the Tien Shan meteorological station. Dotted line shows the annual retreat rate of Petrov glacier. MAP, WST and MAAT values are reported for periods 1930-97 and 1998-2009.

massif (Khromova and others, 2003; Aizen and others, 2006) and nearby Terskey-Alatoo (Narama and others, 2006; Kutuzov and Shahgedanova, 2009). The highest values of the Petrov glacier retreat rates are in the 1990s, which is consistent with the observations made in the Akshiirak massif by Khromova and others (2003). Accelerated recession was also reported from the northern Tien Shan where the annual reduction of glacier area doubled after 1986 (Niederer and others, 2008). In the central and eastern Tien Shan, the recession rate also increased but not so much ( $\mathrm{Li}$ and others, 2006; Narama and others, 2006). Since the beginning of the 21 st century, the glaciers in the study area have increasingly retreated. The described trend is in agreement with observations of Narama and others (2010b), who reported slightly higher recession rates in 2000-07 than in previous decades within the northern and central Tien Shan.

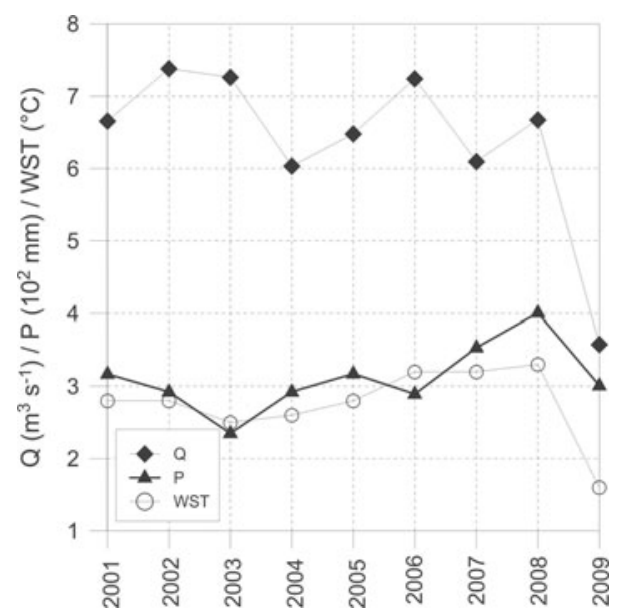

Fig. 8. Annual discharge of the Kumtor river (Q), precipitation (P) and warm-season temperatures (WST) at the Tien Shan meteorological station 2001-09.
A number of studies indicate that the spatial and temporal variations of glaciers in the Tien Shan over the 20th century were controlled by climate changes. However, there is disagreement about the main climate factor that controls glacier fluctuations. With the exception of Bondarev (1963), who related glacial fluctuations primarily to changes in annual precipitation, authors mostly considered air temperature as the main factor controlling glacier mass balance (Bakov, 1983; Glazirin and Faizrachmanov, 1988; Aizen and Aizen, 1994; Solomina and others, 2004; Han and others, 2006). According to Aizen and others (1997), an increase in air temperature extends the period and intensity of melt and increases glacier recession. Recent studies of the climate data from the Tien Shan station showed that air temperatures observed between May and September were the main

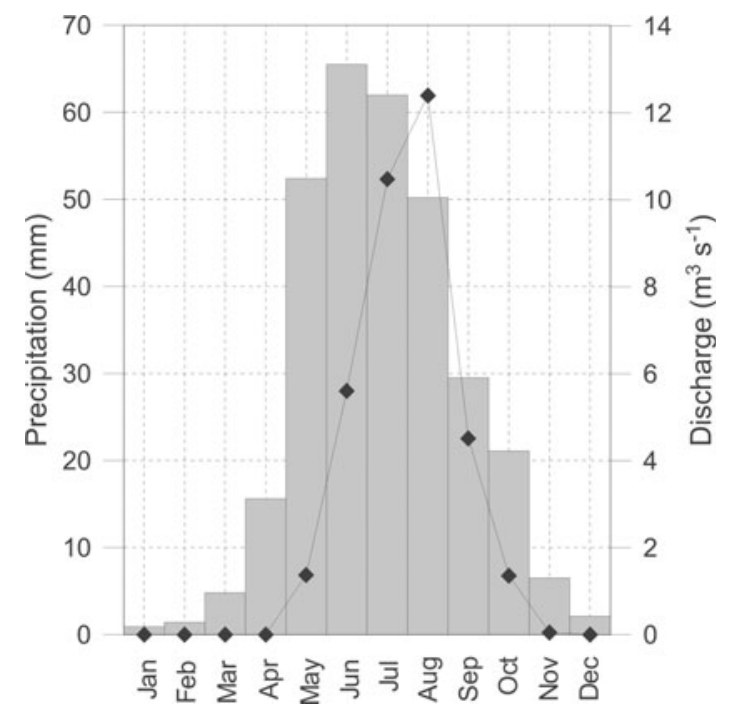

Fig. 9. Precipitation (bars) and monthly discharge for the Kumtor drainage area. 
factors controlling the fluctuations of Akshiirak glaciers in the second half of the 20th century (Aizen and others, 2006). Results presented in this study confirm this view, as the WST from 1943 to 1995 correlates with the Petrov glacier retreat rate $(r=-0.922, p=0.03)$. A strong negative correlation implies the importance of the ablation-season warming for glacier retreat. However, the glacier fluctuations were also closely interconnected with precipitation $(r=0.943$, $p=0.02$ ). The statistically significant correlation between the climate data and glacier retreat was not found for the period 1999-2009. The lack of a significant relation results from the short time series and limited number of described recession periods.

Though the changes of the Petrov glacier length are controlled in particular by climate, differences between the retreat rates of the northern and southern sections of the glacier terminus imply modification of the fluctuations by local environmental factors. According to our results, the differences in retreat rates started to increase during the period 1999-2003 and increased considerably after 2003. The bathymetric map (Fig. 4) shows that the glacier terminus has retreated under different conditions since the 1990s. The northern flow unit started to retreat from a relatively shallow and less inclined part of the lake basin into its entrenched deepest part. In contrast, the southern glacier section retreated back into the shallow eastern end of the lake basin and became land-terminating by 2003. As the southern terminus retreated from the lake and started to move back across the till sheet, its recession decreased substantially. Since the end of the 1990s, the average retreat rate of the southern land-terminating terminus has been two to three times lower than the retreat rate of the northern terminus (in a proglacial lake). The contrast in retreat rates is further enhanced by the fact that the southern flow unit is about half as thick as the northern flow unit and is partly frozen to its bed. The difference between the retreat rates of the land-based and calving glacier sections is in agreement with the notion that calving into proglacial lakes accelerates glacier advances and retreat rates (Warren and Aniya, 1999; Naruse and Skvarca, 2000; Tsutaki and others, 2011). Similar differences of retreat rates were described in the nearby Terskey-Alatoo, where a number of proglacial lakes were formed in the second half of the 20th century. The central part of Popov glacier retreated in a lake environment by $190 \mathrm{~m}$ between 1956 and 1965, while sections outside the lake retreated by only $70 \mathrm{~m}$ (Kutuzov and Shahgedanova, 2009). The same authors further noted an $80 \mathrm{~m}$ difference in retreat between lake-calving and land-terminating sections of south Ashu-Tor glacier in 1977-2006.

The observed rate of calving flux is difficult to link with the mass loss of calving glaciers in the Tien Shan owing to the limited availability of data. Mayer and others (2008) found that the calving flux from southern Inylchek glacier, central Tien Shan, to glacier-dammed Merzbacher lake is $12 \times 10^{6} \mathrm{~m}^{3}$, which is substantially more than the estimated calving flux of Petrov glacier. This is probably related to the higher horizontal surface velocity of the larger Inylchek glacier (up to $0.8 \mathrm{~m} \mathrm{~d}^{-1}$ ) compared with the much slower (up to $0.1 \mathrm{~m} \mathrm{~d}^{-1}$ ) ice front of Petrov glacier (Bakov, 1983; Dyurgerov and others, 1995; Mayer and others, 2008). Although existing estimates of the calving flux are inherently variable (Warren and Aniya, 1999; Van der Veen, 2002), our estimates of total mass loss due to calving from Petrov glacier are consistent with computed wastage of lake-calving glaciers in the Swiss Alps and Alaska. Funk and Röthlisberger (1989) reported calving fluxes of six glaciers in the Alps in the range $5.7-11.6 \times 10^{6} \mathrm{~m}^{3}$. According to Boyce and others (2007), the mean annual mass loss of Mendenhall Glacier, Coast Mountains, Alaska, was $0.75 \times 10^{7} \mathrm{~m}^{3}$ w.e. over the period 2002-05. In contrast, the mean annual calving flux reported for glaciers in Patagonia was two orders of magnitude higher at the end of the 20th century (Warren and Aniya, 1999; Koppes and others, 2011). The higher calving flux of these glaciers, similar to tidewater glaciers, may be attributed to their size and terminus position in deep lakes (Venteris, 1999).

The data on Petrov lake development document substantial increase of the surface area at the end of the 1970s, and continued enlargement during subsequent decades. From 1978 to 2006, the surface area increased at a mean annual rate of $2 \%$, experiencing comparable enlargement to that of the proglacial lake Dzhuuku-5 in the Terskey-Alatoo. The surface area of this moraine-dammed lake at 3830 ma.s.l. grew from $0.133 \mathrm{~km}^{2}$ in 1976 (Sevast'yanov, 1980 ) to $0.254 \mathrm{~km}^{2}$ in 2005 , i.e. at a mean annual rate of $1.6 \%$. The regular annual increase $(1.0-1.5 \%)$ of Petrov lake since 1999 is in contrast to the unstable development of glacial lakes in the Terskey-Alatoo. Area changes of glacier lakes presented by Narama and others (2010a) indicate strong interannual surface variations ranging from about $-25 \%$ to $65 \%$. The difference between surface changes of Petrov lake and that of lakes in the Terskey-Alatoo may be attributed to different volumes and phases of lake development. The surface area of the lakes noted by Narama and others (2010a) is one or two orders of magnitude smaller than the area of Petrov lake, and their sensitivity to annual changes in climate conditions is limited.

\section{SUMMARY AND CONCLUSIONS}

Petrov glacier had undergone relatively small annual oscillations until 1977, retreating at a mean rate of $13.6 \mathrm{~m} \mathrm{a}^{-1}$. At the end of the 1970s, the recession increased substantially and an accelerated retreat followed during the next three decades. Three periods of rapid glacier retreat (1977-80, 1990-95 and 2008-09) separated by two intervals with a reduced retreat occurred during this time. The rate of recession was highest between 1990 and 1995, when a mean annual retreat of $54.1 \pm 8.2 \mathrm{~m}$ occurred along the centre flowline of the glacier. Between 1977 and 2009, the glacier retreated at a mean rate of $40.6 \pm 0.5 \mathrm{~m} \mathrm{a}^{-1}$ and the surface area of the glacier terminus decreased at a rate of $0.07 \pm 0.0002 \mathrm{~km}^{2} \mathrm{a}^{-1}$. The increased retreat rate of Petrov glacier during this period coincides with the accelerated glacier wastage reported from various regions in the Tien Shan. The observed length changes of the glacier correlate with warm-season air temperatures recorded in the second half of the 20th century. A negative correlation between warm-season temperatures and retreat rate indicates the importance of the ablation-season warming for glacier retreat. Between the periods 1930-97 and 1998-2009, the mean temperature and the length of the ablation season increased by $0.8^{\circ} \mathrm{C}$ and by 0.6 months, respectively. However, the correlation between climate conditions and glacier retreat was not found for the period 1999-2009.

The lake-terminating northern section of the Petrov glacier terminus has retreated at rates up to three times higher than the land-terminating southern part since 1995. 
The difference in retreat rate may be attributed to intense calving of the northern section in a proglacial environment and to subfreezing conditions in the marginal parts of the southern part of the glacier base. The calving accounted for a total mass loss of $(17.7 \pm 0.4) \times 10^{6} \mathrm{~m}^{3}$ from the calving glacier terminus in 2003-09. The mean annual calving flux reached typical values reported for alpine lake-calving glaciers. The calving terminus of Petrov glacier is more than $65 \mathrm{~m}$ thick according to GPR measurements, whereas the maximum thickness of the southern flow unit is about $38 \mathrm{~m}$. The surface lowering of the glacier terminus ranged from $2 \mathrm{~m}$ in debris-covered areas to $5 \mathrm{~m}$ in sections exposed to direct insolation from 2006 to 2009.

The fluctuations of Petrov glacier controlled the growth of the area and volume of Petrov lake. The mean annual changes of the lake surface area were low until the late 1970 s, ranging up to $0.03 \mathrm{~km}^{2} \mathrm{a}^{-1}$. After 1978, the surface enlargement increased and remained high for the next three decades. The mean annual enlargement by $0.04-0.1 \mathrm{~km}^{2}$ is in agreement with the lake surface changes in the central Tien Shan over the past three decades. The mean annual volume increase ranged from $(1.3 \pm 0.012) \times 10^{6} \mathrm{~m}^{3}$ to $(2.2 \pm 0.009) \times 10^{6} \mathrm{~m}^{3}$ in $1978-2009$. The volume enlargement increased considerably in 2003-06, when the calving glacier terminus retreated from the deepest part of the lake basin. The decrease in the depth of the lake basin and rising bed topography below the calving glacier terminus detected by the GPR survey imply that the increase in volume will not be as fast in the near future. The retreat rate of Petrov glacier is likely to be affected by the decrease in the depth of the lake, hence a slower retreat may be expected in the near future. This piece of knowledge was unknown to authors of hazard assessments from Petrov lake outbursts (e.g. Janský and others, 2010) and it should stimulate further studies.

\section{ACKNOWLEDGEMENTS}

We thank the Kumtor Mining Co. for providing climate, discharge and topography data as well as permission to work in the region. Fieldwork was funded by the Czech Ministry for Environment (194/07-09/MŽP/B) and by the Czech Ministry of Education (MSM 0021620831).

\section{REFERENCES}

Aizen VB and Aizen EM (1994) Features of regime and mass exchange of some glaciers on central Asia periphery. Bull. Glacier Res., 12, 9-24

Aizen VB, Aizen EM, Melack JM and Dozier J (1997) Climatic and hydrological change in the Tien Shan, central Asia. J. Climate, 10(6), 1393-1404

Aizen VB, Kuzmichenok VA, Surazakov A and Aizen E (2006) Glacier changes in the central and northern Tien Shan during the last 140 years based on surface and remote-sensing data. Ann. Glaciol., 43, 202-213 (doi: 10.3189/172756406781812465)

Aizen VB, Kuzmichenok VA, Surazakov AB and Aizen EM (2007) Glacier changes in the Tien Shan as determined from topographic and remotely sensed data. Global Planet. Change, 56(3-4), 328-340.

Avsiuk GA (1953) Lednik Petrova [Petrov glacier]. Raboty Tyan'Shanskoy Fiziko-Geograficheskoy Stantsii 2a. Izdatelsvto Akademii Nauk SSSR, Moscow, 103-131

Bakov EK (1983) Zakonomernosti dvizenia i dinamiki lednikov Centralnogo Tian-Shanya [Principles of glacier movements and dynamics in central Tien Shan]. Ilim, Frunze
Bolch T (2007) Climate change and glacier retreat in northern Tien Shan (Kazahkstan/Kyrgyzstan) using remote sensing data. Global Planet. Change, 56(1-2), 1-12 (doi: 10.1016/ j.gloplacha.2006.07.009)

Bondarev LG (1963) Ocherki po oledeneniyu massiva Ak-Shirak [Studies on the glaciation of the Ak-Schyirak Range]. Izdatelstvo Akademii Nauk Kirgizskoi SSR, Frunze

Boyce ES, Motyka RJ and Truffer M (2007) Flotation and retreat of a lake-calving terminus, Mendenhall Glacier, southeast Alaska, USA. J. Glaciol., 53(181), 211-224 (doi: 10.3189/ 172756507782202928)

Davis JL and Annan AP (1989) Ground-penetrating radar for high-resolution mapping of soil and rock stratigraphy. Geophys. Prospect., 37(5), 531-551 (doi: 10.1111/j.1365-2478. 1989.tb02221.x)

Davydov LK (1927) Lednik Petrova [Petrov glacier]. Trudy Gidromet. Otdel. Sred. Meteorol. Inst., 1(1), 67-100 [In Russian]

Dikich AN, Bakov EK, Koshoev MK, Melnikova AP and Dikich LL (1991) Ledovie resursi Centralnogo Tian-Shanya. Ilim, Bishkek

Dolgushin LD and Osipova GB (1982) Pul'siruyushchie ledniki [Surging glaciers]. Gidrometeoizdat, Leningrad

Dyurgerov MB, Liu C and Xie Z (1995) Oledenenie Tyan'-Shanya [Tien Shan glaciers]. VINITI, Moscow

Ermolin ED, Nemov AE and Popov MV (1989) Geotermicheskaya kharakteristika mestorozhdeniya Kumtor. In Geokriologicheskiye issledovaniya v goraj CCCP [Geocryological investigations in the mountains of USSR]. Institute of Permafrost Research, Yakutsk, 31-40

Funk $M$ and Röthlisberger $H$ (1989) Forecasting the effects of a planned reservoir which will partially flood the tongue of Unteraargletscher in Switzerland. Ann. Glaciol., 13, 76-81

Garmin (2007) GPSMap 178/178C: owner's manual, Garmin International, Olathe, KS

Glazirin GE and Faizrachmanov SK (1988) Kolebaniya lednikov Sredney Azii za poslednie 20 let i ikh svyaz s izmeneniem klimata. Trudi SANII, 91(172), 72-81

Gorbunov AP, Seversky EV and Titkov SN (1996) Geocryologicheskie usloviya Tyan-Shanya i Pamira [Geocryological conditions in the Tien Shan and Pamir]. Permafrost Institute Press, Yakutsk

Hall DK, Bayr KJ, Schöner W, Bindschadler RA and Chien JYL (2003) Consideration of the errors inherent in mapping historical glacier positions in Austria from ground and space (1893-2001). Remote Sens. Environ., 86(4), 566-577

Han T, Ding Y, Ye B, Liu S and Jiao K (2006) Mass-balance characteristics of Ürümqi glacier No. 1, Tien Shan, China. Ann. Glaciol., 43, 323-328 (doi: 10.3189/172756406781811961)

Ivanov MB ed. (1964) Seria Alay-Kokshaalskaya. Geological map 1:200,000. BAGT, Leningrad

Janský B, Engel Z, Šobr M, Beneš V, Špaček K and Yerokhin S (2009) The evolution of Petrov lake and moraine dam rupture risk (TienShan, Kyrgyzstan). Natur. Hazards, 50(1), 83-96 (doi: 10.1007/ s11069-008-9321-8)

Janský B, Šobr M and Engel Z (2010) Outburst flood hazard: case studies from the Tien-Shan Mountains, Kyrgyzstan. Limnologica, 40(4), 358-364

Kalesnik SV and Epstein SV (1935) Lednikovij uzel Ak-Shyirak [Akshiirk glacier knot]. Trudi Lednik. Exped., 2, 321-372

Kaulbars AV (1875) Materiali po geographii Tien Shanya sobrannie vo vremya puteshestviya 1869 [Materials on Tien Shan geography, collected within 1869 expedition]. Proc. Russ. Geogr. Soc., 5, 253-539

Khromova T (2005) GLIMS glacier database, National Snow and Ice Data Center/World Data Center for Glaciology, Boulder, CO. Digital media: nsidc.org/glims

Khromova TE, Dyurgerov MB and Barry RG (2003) Late-twentieth century changes in glacier extent in the Ak-shirak Range, Central Asia, determined from historical data and ASTER imagery. Geophys. Res. Lett., 30(16), 1863 (doi: 10.1029/2003GL017233)

Koppes M, Conway H, Rasmussen LA and Chernos M (2011) Deriving mass balance and calving variations from reanalysis 
data and sparse observations, Glaciar San Rafael, northern Patagonia, 1950-2005. Cryosphere, 5(3), 791-808 (doi: 10.5194/tc-5-791-2011)

Koshoev MK (1986) Kolebaniya lednikov Central'nogo Tian-Shania vXX veke. In Rezim lednikov Central'nogo Tyan-Shanya [Fluctuations of glaciers in the central Tien Shan in the 20th century]. Ilim, Frunze, 31-59

Kutuzov S and Shahgedanova M (2009) Glacier retreat and climatic variability in the eastern Terskey-Alatoo, inner Tien Shan between the middle of the 19th century and beginning of the 21st century. Global Planet. Change, 69(1-2), 59-70 (doi: 10.1016/j.gloplacha.2009.07.001)

Kuzmichenok VA (1990) Izmenenie lednikov khrebta Akshiirak c 1943 po 1977 godi. (Scale 1:50,000) Main Department of Geodesy and Cartography of the USSR, Moscow

Li B, Zhu A-X, Zhang Y, Pei T, Qin C and Zhou C (2006) Glacier change of the past four decades in the middle Chinese Tien Shan. J. Glaciol., 52(178), 425-432 (doi: 10.3189/ 172756506781828557)

Main Department of Geodesy and Cartography of the USSR (1981) Map No. U-41-82-B-Г (Scale 1:25000). Main Department of Geodesy and Cartography of the USSR, Moscow

Makarevich KG and Liu S (1995) Izmenieniya oledeneniya Tian-Shania $v X X$ veke [Changes of Tien Shan glaciation in the 20th century]. In Dyurgerov MB, Liu S and Xie Z eds. Oledenenie Tian-Shania [Tien-Shan glaciers]. VINITI, Moscow, 189-213

Maksimov EV (1980) Lednikovoe proshloe khrebta Kirgizskiy Alatau [The glacial past of the Kirghiz Alatau Mountain range], Izdatelstvo Leningradskogo Universiteta, Leningrad [In Russian]

MALÅ GeoScience (2005) Ramac GPR. Hardware manual. MALA GeoScience, Malå

Mayer C, Lambrecht A, Hagg W, Helm A and Scharrer K (2008) Post-drainage ice dam response at Lake Merzbacher, Inylchek Glacier, Kyrgyzstan. Geogr. Ann., Ser. A, 90(1), 87-96 (doi: 10.1111/j.1468-0459.2008.00336.x)

Meiners S (1997) Historical to Post Glacial glaciation and their differentiation from the Late Glacial period on examples of the Tian Shan and the N.W. Karakorum. Geolournal, 42(2-3), 259-302

Narama C, Shimamura Y, Nakayama D and Abdrakhmatov K (2006) Recent changes of glacier coverage in the western TerskeyAlatoo range, Kyrgyz Republic, using Corona and Landsat. Ann. Glaciol., 43, 223-229 (doi: 10.3189/172756406781812195)

Narama C, Duishonakunov M, Kääb A, Daiyrov M and Abdrakhmatov K (2010a) The 24 July 2008 outburst flood at the western Zyndan glacier lake and recent regional changes in glacier lakes of the Teskey Ala-Too range, Tien Shan, Kyrgyzstan. Natur. Hazards Earth Syst. Sci. (NHESS), 10(4), 647-659 (doi: 10.5194/ nhess-10-647-2010)

Narama C, Kääb A, Duishonakunov M and Abdrakhmatov K (2010b) Spatial variability of recent glacier area changes in the Tien Shan Mountains, Central Asia, using Corona ( 1970), Landsat ( 2000), and ALOS ( 2007) satellite data. Global Planet. Change, 71(1-2), 42-54 (doi: 10.1016/j.gloplacha. 2009.08.002)
Naruse R and Skvarca P (2000) Dynamic features of thinning and retreating Glaciar Upsala, a lacustrine calving glacier in southern Patagonia. Arct. Antarct. Alp. Res., 32(4), 485-491

Niederer P, Bilenko V, Ershova N, Hurni H, Yerokhin S and Maselli D (2008) Tracing glacier wastage in the Northern Tien Shan (Kyrgyzstan/Central Asia) over the last 40 years. Climatic Change, 86 (1-2), 227-234 (doi: 10.1007/s10584-007-9288-6)

Savoskul OS (1995) Kolebaniya lednika Petrova v posledniem tisyacheletii. Mater. Glyatsiol. Issled. 79, 134-139

Sevast'yanov DV (1980) Malie ozera Vnutrennego Tian-Shanya [Small lakes of the inner Tien Shan]. In Ozera Tian-Shanya I ikh istoriya [Tien Shan lakes and their history]. Nauka, Leningrad, $150-221$

Sevast'yanov DV and Funtikov AB (1981) Novy dannye ob evollucii vysokogornogo ozera u konca lednika Petrova [New data on the evolution of the mountainous lake in front of the Petrov glacier]. Izv. VGO, 113(5), 430-435

Solomina O, Barry R and Bodnya M (2004) The retreat of Tien Shan glaciers (Kyrgyzstan) since the Little Ice Age. Geogr. Ann., 86(2), 205-215 (doi: 10.1111/j.0435-3676.2004.00225.x)

Suslov VF (1973) Katalog lednikov SSSR - Srednyaya Aziya [Glacier Inventory of the USSR - Central Asia], Tom 14, Vol. 1, Syrdarya, Part 5. Gidrometeoizdat, Leningrad

Trimble (2009) GeoExplorer 2008 series. User guide. Tremble Navigation, Sunnyvale, CA

Tsutaki S, Nishimura D, Yoshizawa T and Sugiyama S (2011) Changes in glacier dynamics under the influence of proglacial lake formation in Rhonegletscher, Switzerland. Ann. Glaciol., 52(58), 31-36 (doi: 10.3189/172756411797252194)

Van der Veen CJ (2002) Calving glaciers. Progr. Phys. Geogr., 26(1), 96-122

Venteris ER (1999) Rapid tidewater glacier retreat: a comparison between Columbia Glacier, Alaska and Patagonian calving glaciers. Global Planet. Change, 22(1-4), 131-138

Vilesov EN and Uvarov VN (2001) Evolyutsiya savremennogo oledenenya Zailiyskogo Alatau $v$ XX Veke [The evolution of modern glaciation of the Zailiskiu Alatau in the 20th century]. Kazakh State University, Almaty

Vilesov Y, Makarevich KG and Polyakov VG (1993) Prostranstvenno-vremennaya ismenchivost' lednikovoy sistemy Zailiyskogo Alatay [Space-time variability of the glacier system in Zailiysky Alatay]. Mater. Glyatsiol. Issled. 76, 90-95 [In Russian with English summary]

Voloshina AP (1988) Klimaticheskiye i meteorologicheskiye osobennosti rayona oledeneniya massiva Akshiyrak [Climatic and meteorological peculiarities of the glacierized area of the Akshiyrak range]. Mater. Glyatsiol. Issled. 62, 184-193 [In Russian with English summary]

Warren C and Aniya M (1999) The calving glaciers of southern South America. Global Planet. Change, 22(1-4), 59-77

Yao TD, Wang YQ, Liu SY, Pu JC, Shen YP and Lu AX (2004) Recent glacial retreat in High Asia in China and its impact on water resource in Northwest China. Sci. China D, 47(12), 1065-1075

Yermolov AA, Solodkov PA and Firsov MI (1986) Kolebaniya lednikov Ak-Suu Vostochniy, Ak-Suu Zapadniy i Dolonata za period 1921-1982. Trudi SARNIGMI, 117(198), 103-110 